\title{
SOSIALISASI DAN PENYULUHAN UNDANG-UNDANG NOMOR 21 TAHUN 2007 TENTANG PEMBERANTASAN TINDAK PIDANA PERDAGANGAN ORANG DI DESA LEBAK KEPUH KECAMATAN LEBAK WANGI SEBAGAI KANTUNG TKW DI KABUPATEN SERANG
}

\author{
Riswanda, Rahmawati Allyreza \\ Program Studi Ilmu Administrasi Publik FISIP Universitas Sultan Ageng Tirtayasa \\ Corresponding Author, Email: rahmawati@untirta.ac.id
}

\begin{abstract}
Becoming a female worker abroad, especially in Middle Eastern countries, Malaysia is the dream and hope for most women and families in Lebak Kepuh Village. Working as farm laborers and getting caught up in loan sharks forced these families to send their children to become TKW. Private Indonesian Employment Service Delivery Companies (PPTKIS) have sprung up as a connector between workers and overseas job providers. This activity aims to socialize Law Number 21 of 2017 concerning the Eradication of the Crime of Trafficking in Persons. The causes, methods, methods and consequences of victims of trafficking in persons are presented and described in this activity. This includes serious legal sanctions that will be imposed on parties who deliberately commit the criminal act of trafficking in persons. Village officials ranging from neighborhood units, neighborhood units to village officials are at the forefront of preventing criminal acts of trafficking in persons because the form of trafficking begins with manipulating population data for poor families who want to send their children to work in public families, reporting companies that supply illegal foreign workers to the authorities. is an effort to stop the criminal act of trafficking in persons (women) in Desa Lebak Kepuh, Kecamatan Lebak, Serang Regency.
\end{abstract}

Keywords: criminal acts, human trafficking, female labor

\begin{abstract}
Abstrak
Menjadi Tenaga Kerja Wanita di luar negeri khususnya Negara Timur Tengah, Malaysia merupakan idaman dan harapan bagi sebagian besar perempuan dan keluarga yang ada di Desa Lebak Kepuh. Bekerja sebagai buruh tani dan terjerat pada utang lintah darat memaksa keluarga-keluarga tersebut untuk mengirimkan anaknya menjadi TKW. Perusahaan Pengiriman Jasa Tenaga Kerja Indonesia Swasta (PPTKIS) marak bermunculan sebagai penyambung tenaga kerja dengan penyedia lapangan kerja di luar negeri. Kegiatan ini bertujuan untuk mensosialisasikan Undang-Undang Nomor 21 Tahun 2017 tentang Pemberantasan Tindak Pidana Perdagangan Orang. Factor penyebab, cara, metode dan akibat dari korban perdagangan orang disampaikan dan dipaparkan dalam kegiatan ini. Termasuk juga sanksi hukum yang berat akan dikenakan kepada pihak-pihak yang dengan sengaja melakukan tindak pidana perdagangan orang. Perangkat desa mulai dari rukun tetangga, rukun warga sampai dengan pegawai desa menjadi garda terdepan mencegah tindak pidana perdagangan orang karena bentuk perdagangan orang diawali dengan memanipulasi data kependudukan keluarga miskin yang ingin mengirimkan anaknya bekerja keluarga negeri, melaporkan perusahaan penyalur tenaga kerja asing illegal ke pihak berwajib merupakan upaya menghentikan tindak pidana perdagangan orang (perempuan) di Desa Lebak Kepuh Kecamatan Lebak Wangi Kabupaten Serang.
\end{abstract}

Kata kunci: tindak pidana, perdagangan orang, tenaga kerja wanita

(C) 2020 Penerbit PS2PM FISIPKUM UNSERA

(C) 2020 Segala bentuk plagiarisme dan penyalahgunaan hak kekayaan intelektual akibat diterbitkannya artikel pengabdian masyarakat ini sepenuhnya menjadi tanggung jawab penulis

Riswanda, Rahmawati. Sosialisasi dan Penyuluhan Undang-undang Nomor 21 tahun 2007 tentang Pemberantasan Tindak Pidana Perdagangan Orang di Desa Lebak Kepuh Kecamatan Lebak Wangi sebagai kantung TKW di Kabupaten Serang

Halaman 87-97 


\section{Pendahuluan}

Menurut laporan dari US Embassy di Indonesia, Masing-masing propinsi dari 33 propinsi di Indonesia merupakan daerah sumber dan tujuan perdagangan manusia, dengan daerah sumber yang paling signifikan adalah Jawa, Kalimantan Barat, Lampung, Sumatera Utara, dan Sumatera Selatan. Sejumlah besar pekerja migran Indonesia menghadapi kondisi kerja paksa dan terjerat utang di negaranegara Asia yang lebih maju dan Timur Tengah - khususnya Malaysia, Arab Saudi, Singapura, Kuwait, Suriah, dan
Irak. Jumlah Warga Negara Indonesia yang bekerja di luar negeri masih sangat tinggi, diperkirakan 6,5 juta sampai 9 juta pekerja migran Indonesia di seluruh dunia, termasuk 2,6 juta manusia di Malaysia dan 1,8 juta manusia di Timur Tengah. Diperkirakan 69 persen dari seluruh Tenaga Kerja Indonesia di luar negeri adalah perempuan.

Menurut data KBRI Malaysia menyatakan tahun 2011 jumlah TKI yang mengalami permasalahan ketenagakerjaan sebagai berikut:

\begin{tabular}{lll}
\hline \multicolumn{1}{c}{ No } & \multicolumn{1}{c}{ Permasalahan TKI } & \multicolumn{1}{c}{ Jumlah } \\
\hline 1. & Gaji tidak dibayarkan & 1001 \\
\hline 2. & Disharmoni dalam Pekerjaan & 275 \\
\hline 3. & Eksploitasi & 51 \\
\hline 4. & Pemberhentian secara sepihak & 13 \\
\hline 5. & Ketidaksesuaian pekerjaan & 174 \\
\hline 6. & Kekerasan fisik & 57 \\
\hline 7. & Perdagangan manusia & 59 \\
\hline 8. & Sakit/stress & 52 \\
\hline 9. & Terlantar/illegal & 90 \\
\hline 10. & Kriminal & 16 \\
\hline 11 & Meninggal dunia & 50 \\
\hline 12. & Kecelakaan & 15 \\
\hline
\end{tabular}

Sumber: Republika, 22 Desember 2011

Riswanda, Rahmawati. Sosialisasi dan Penyuluhan Undang-undang Nomor 21 tahun 2007 tentang Pemberantasan Tindak Pidana Perdagangan Orang di Desa Lebak Kepuh Kecamatan Lebak Wangi sebagai kantung TKW di Kabupaten Serang 
IOM (International Organization for Migration) dan LSM antiperdagangan manusia terkemuka di Indonesia memperkirakan bahwa 43 sampai 50 persen - atau sekitar 3 sampai 4,5 juta - Tenaga Kerja Indonesia di luar negeri menjadi korban dari kondisi yang mengindikasikan adanya perdagangan manusia. Dari 3.840 korban perdagangan manusia yang diidentifikasi IOM dan pemerintah Indonesia saat kembali dari bekerja di luar negeri, 90 persen adalah perempuan dan 56 persen telah dieksploitasi dalam pekerjaan rumah tangga. Menurut IOM, total 82 persen korban yang diidentifikasi pada tahun 2010 telah menjadi korban perdagangan manusia ke luar negeri; 18 persen diantaranya menjadi korban perdagangan manusia di Indonesia.

$$
\text { Para korban perdagangan }
$$

manusia di Indonesia melaporkan mengalami bentuk-bentuk pelecehan yang kesemuanya kondusif untuk perdagangan manusia yaitu: gaji ditahan (85 persen); jam kerja berlebihan (80 persen); pembatasan pergerakan (77 persen); pelecehan verbal atau psikologis (75 persen), dan penyitaan dokumen perjalanan (66 persen). Jumlah perempuan Indonesia yang diperkosa saat bekerja sebagai pekerja rumah tangga tampaknya meningkat. Berdasarkan survei tahun 2010, LSM Indonesia yang disegani mencatat bahwa selama tahun tersebut 471 migran Indonesia kembali dari Timur Tengah tengah hamil akibat perkosaan, dan 161 manusia lainnya kembali dengan anak-anak yang telah lahir di Timur Tengah. Setengah dari korban perdagangan manusia di dalam negeri adalah anak-anak, sementara 70 persen korban perdagangan manusia ke luar negeri adalah manusia dewasa.

Menurut IOM, perusahaan yang merekrut Tenaga Kerja Indonesia, baik legal dan ilegal, bertanggung jawab atas lebih dari 50 persen tenaga kerja

Riswanda, Rahmawati. Sosialisasi dan Penyuluhan Undang-undang Nomor 21 tahun 2007 tentang Pemberantasan Tindak Pidana Perdagangan Orang di Desa Lebak Kepuh Kecamatan Lebak Wangi sebagai 
perempuan yang mengalami kondisi perdagangan manusia di negara tujuan. Beberapa perusahaan tersebut bekerja secara mandiri, yang lain untuk perusahaan perekrutan tenaga kerja yang disebut PJTKI/Perusahaan Jasa tenaga Kerja Indonesia (baik perusahaan legal maupun ilegal). Beberapa PJTKI beroperasi layaknya sindikat perdagangan manusia, mengarahkan baik pekerja laki-laki dan perempuan ke dalam jeratan utang dan situasi perdagangan perbudakan lainnya. Perantara perekrutan ini sering beroperasi di luar hukum karena memiliki impunitas (kebal hukum) dan beberapa PJTKI menggunakan hubungan dengan pejabat pemerintah atau polisi untuk menghindari hukuman.

Ada laporan calon pekerja yang direkrut untuk bekerja di luar negeri oleh PJTKI ditahan paksa selama berbulan-bulan di kompleksnya seakan-akan untuk pelatihan dan proses - sebelum dikirimkan ke negara tujuan, menumpuk utang yang membuat calon pekerja menjadi rentan masuk ke dalam jeratan utang. Perusahaan yang mempunyai izin maupun tidak menggunakan jeratan utang, menahan dokumen, ancaman kekerasan, dan penahanan di tempat terkunci untuk waktu yang lama untuk menjaga calon Tenaga Kerja Indonesia dalam situasi kerja paksa.

$$
\text { Berdasarkan data BNP2TKI }
$$
Banten tahun 2008, Kabupaten Serang menempati angka tertinggi dalam penempatan TKI ke luar negeri yaitu 3.768 manusia. Disusul dengan Kabupaten Tangerang 1.705 manusia, Kabupaten Lebak 1.531 manusia, Kota Cilegon 134 manusia dan Kota Tangerang 14 manusia. Kantung TKI di Kabupaten Serang adalah Kecamatan Lebak Wangi dan Kecamatan Tirtayasa. Desa Lebak Kepuh Kecamatan Lebak Wangi merupakan salah satu kantung Tenaga Kerja Indonesia, terutama 
Tenaga Kerja Wanita yang biasanya

dikirimkan ke negara timur tengah dan malaysia.

Berdasarkan hasil penelitian yang dilakukan oleh Syamsuri, dkk tahun 2008 tentang Persepsi Keluarga tentang Motivasi Kaum Perempuan menjadi TKW ke Luar Negeri dan Pengaruhnya terhadap Tingkat Kemiskinan menyatakan bahwa motivasi kaum perempuan Kecamatan Lebak Wangi menjadi TKW adalah motivasi ekonomi karena kemiskinan dan motivasi pribadi. Karakteristik perempuan menjadi TKW karena motivasi ekonomi mendapatkan dukungan keluarga lebih besar dan memiliki keyakinan kesejahteraan keluarga akan meningkat ketika menjadi TKW. Sementara perempuan yang menjadi TKW karena motivasi pribadi kurang mendapatkan dukungan dari pihak keluarga.
Provinsi Banten sendiri melalui P2TP2A mencatat bahwa selama tahun 2013 terjadi 123 kasus perdagangan yang menimpa pada 22 laki-laki dan 101 perempuan. Angka ini tidaklah sedikit dan harus menjadi perhatian pemerintah karena kasus perdagangan anak biasanya menggunakan modus bekerja di luar negeri dengan imingiming seluruh biaya pemberangkatan ditanggung oleh agen (sponsor) atau perusahaan, untuk kemudian para pekerja ini dieksploitasi tenaganya atau tubuhnya. Berdasarkan latar belakang di atas terdapat anggapan yaitu keluarga perempuan yang ingin menjadi TKW karena alasan ekonomi lebih mudah terbujuk rayu oleh oknum/organisasi perdagangan manusia dengan kedok perusahaan pengiriman TKI untuk kemudian mengeksploitasi perempuan atau tenaga kerja asal Pontang bahkan diperdagangkan. 


\section{Metode Pelaksanaan}

Metode kegiatan pengabdian kepada masyarakat dengan tahapan sistematis berikut:

1. Peserta pelatihan diberikan penyuluhan tentang UU No. 21 Tahun 2007

2. Peserta diberi penyuluhan tentang jenis, metode dan strategi perdagangan manusia

3. Peserta diberikan kesempatan tanya jawab tentang materi yang diberikan bila ada hal-hal yang belum jelas dan tidak dipahami;

4. Peserta pelatihan diberikan kesempatan terbuka untuk menyampaikan kondisi yang pernah dialami

5. Peserta pelatihan melakukan crosscheck hasil pelatihan yang telah dibuat dengan yang sudah dilakukan sebelum penyuluhan untuk mengukur ketercapaian materi yang disampaikan.

\section{Hasil dan Pembahasan}

Desa Lebak Kepuh Kecamatan Lebak Wangi merupakan salah satu desa pemekaran dari Kecamatan Pontang. Batas wilayah Desa Lebak Kepuh sebagai berikut: 1)Sebelah Utara : Desa Pulo Kencana, 2)Sebelah Selatan: Desa Tirem, Sebelah Barat: Desa Linduk, Sebelah Timur : Desa Kencana Harapan

Jumlah penduduk sebanyak 2.972 jiwa dengan jumlah penduduk laki-laki sebanyak 1.440 jiwa dan penduduk perempuan sebanyak 1.532 jiwa. Struktur mata pencaharian penduduk Desa Lebak Kepuh antara lain pemilik tanah sawah 37 orang, penyewa atau penggarap 30 orang dan buruh tani sebanyak 956 orang. Dari data tersebut jelas terlihat bagaimana kondisi sosial ekonomi mayoritas masyarakat Desa Lebak Kepuh. Buruh tani adalah kondisi dimana, bekerja sebagai buruh pada pemilik lahan pertanian dengan system bagi hasil.

Riswanda, Rahmawati. Sosialisasi dan Penyuluhan Undang-undang Nomor 21 tahun 2007 tentang Pemberantasan Tindak Pidana Perdagangan Orang di Desa Lebak Kepuh Kecamatan Lebak Wangi sebagai kantung TKW di Kabupaten Serang 
Bagi hasil tersebut dilakukan setelah panen, dimana buruh tani mendapatkan bayaran atas hasil penjualan gabah kering untuk biaya pupuk, bibit dan perawatan. Karena factor ekonomi keluarga menjadi pendorong utama keluarga di Desa Lebak Kepuh yang memiliki anak gadis setelah lulus SD atau SMP digadanggadang untuk mau bekerja sebagai TKW ke wilayah Negara Timur Tengah dan Malaysia. Hal ini lah yang menjadi factor sangat riskan bagi masyarakat Desa Lebak Kepuh akan terjadinya perdagangan orang. Demi mendapatkan kartu tanda penduduk, banyak calon tenaga kerja wanita tersebut dibuat lebih tua atau usia dituakan serta status Pendidikan juga diubah oleh PPTKIS yang bergerilya ke kampung - kampung di Kecamatan Lebak Wangi.

Perdagangan orang adalah bentuk modern dari perbudakan manusia. Perdagangan orang juga merupakan salah satu bentuk perlakuan terburuk dari pelanggaran harkat dan martabat manusia. Bertambah maraknya masalah perdagangan orang di berbagai negara, termasuk Indonesia dan negara-negara yang sedang berkembang lainnya, telah menjadi perhatian Indonesia sebagai bangsa, masyarakat internasional, dan anggota organisasi internasional, terutama Perserikatan Bangsa-Bangsa (PBB). Berdasarkan bukti empiris, perempuan dan anak adalah kelompok yang paling banyak menjadi korban tindak pidana perdagangan orang. Korban diperdagangkan tidak hanya untuk tujuan pelacuran atau bentuk eksploitasi seksual lainnya, tetapi juga mencakup bentuk eksploitasi lain, misalnya kerja paksa atau pelayanan paksa, perbudakan, atau praktik serupa perbudakan itu. Pelaku tindak pidana perdagangan orang melakukan perekrutan, pengangkutan, pemindahan, penyembunyian, atau

Riswanda, Rahmawati. Sosialisasi dan Penyuluhan Undang-undang Nomor 21 tahun 2007 tentang Pemberantasan Tindak Pidana Perdagangan Orang di Desa Lebak Kepuh Kecamatan Lebak Wangi sebagai 
penerimaan orang untuk tujuan menjebak, menjerumuskan, atau memanfaatkan orang tersebut dalam praktik eksploitasi dengan segala bentuknya dengan ancaman kekerasan, penggunaan kekerasan, penculikan, pemalsuan, penipuan, penyalahgunaan kekuasaan atau posisi rentan, atau memberi bayaran atau manfaat sehingga memperoleh persetujuan dari orang yang memegang kendali atas korban.

Bentuk-bentuk eksploitasi meliputi kerja paksa atau pelayanan paksa, perbudakan, dan praktikpraktik serupa perbudakan, kerja paksa atau pelayanan paksa adalah kondisi kerja yang timbul melalui cara, rencana, atau pola yang dimaksudkan agar seseorang yakin bahwa jika ia tidak melakukan pekerjaan tertentu, maka ia atau orang yang menjadi tanggungannya akan menderita baik secara fisik maupun psikis. Perbudakan adalah kondisi seseorang di bawah kepemilikan orang lain. Praktik serupa perbudakan adalah tindakan menempatkan seseorang dalam kekuasaan orang lain sehingga orang tersebut tidak mampu menolak suatu pekerjaan yang secara melawan hukum diperintahkan oleh orang lain itu kepadanya, walaupun orang tersebut tidak menghendakinya.

Pemerintah Indonesia telah mengeluarkan Undang-Undang Nomor 21 Tahun 2007 tentang Pemberantasan Tindak Pidana Perdagangan Orang. Dalam UU tersebut, dijelaskan bahwa Perdagangan Orang adalah tindakan perekrutan, pengangkutan, penampungan, pengiriman, pemindahan, atau penerimaan seseorang dengan ancaman kekerasan, penggunaan kekerasan, penculikan, penyekapan, pemalsuan, penipuan, penyalahgunaan kekuasaan atau posisi rentan, penjeratan utang atau memberi bayaran atau manfaat, sehingga

Riswanda, Rahmawati. Sosialisasi dan Penyuluhan Undang-undang Nomor 21 tahun 2007 tentang Pemberantasan Tindak Pidana Perdagangan Orang di Desa Lebak Kepuh Kecamatan Lebak Wangi sebagai 
memperoleh persetujuan dari orang yang memegang kendali atas orang lain tersebut, baik yang dilakukan di dalam negara maupun antar negara, untuk tujuan eksploitasi atau mengakibatkan orang tereksploitasi. Tindak Pidana Perdagangan Orang adalah setiap tindakan atau serangkaian tindakan yang memenuhi unsur-unsur tindak pidana yang ditentukan dalam Undang-Undang ini. Korban adalah seseorang yang mengalami penderitaan psikis, mental, fisik, seksual, ekonomi, dan/atau sosial, yang diakibatkan tindak pidana perdagangan orang

$$
\text { Kegiatan Pengabdian }
$$

dilaksanakan pada hari Senin tanggal 27 Agustus 2018 bertempat di ruang serba guna Desa Lebak Kepuh. Peserta yang hadir pada kegiatan tersebut antara lain perangkat Desa Lebak Kepuh, BPD, tokoh masyarakat, masyarakat desa dan media massa. Kegiatan diawali dengan pembukaan yang dilakukan oleh kepala Desa Lebak Kepuh Bapak Komalarudin, S. Sos dengan jumlah peserta sebanyak 40 orang.

$\begin{array}{ccc}\text { Kegiatan } & \text { diawali } & \text { dengan } \\ \text { penayangan } & \text { video } & \text { tentang }\end{array}$
perdagangan orang yang terjadi, cara, metode dan pengaruhnya bagi korban serta keluarga. Untuk selanjutnya dipaparkan tentang bagaimana upaya mencegah agar keluarga di Desa Lebak Kepuh tidak mudah percaya kepada orang luar (PPTKIS) yang menawarkan pekerjaan kepada anak perempuan mereka, menjanjikan pekerjaan yang layak dengan gaji yang besar serta menjanjikan akan ada perubahan kondisi ekonomi keluarga jika anak perempuannya mau bekerja sebagai TKW ke luar Negeri.

Oleh karena itu diperlukan peran serta aktif seluruh pihak di desa terutama dari perangkat desa untuk mencegah tindak pidana perdagangan orang. Karena awal mula munculnya

Riswanda, Rahmawati. Sosialisasi dan Penyuluhan Undang-undang Nomor 21 tahun 2007 tentang Pemberantasan Tindak Pidana Perdagangan Orang di Desa Lebak Kepuh Kecamatan Lebak Wangi sebagai 
persoalan perdagangan orang adalah dengan memanipulasi data kependudukan warga. Garda terdepan pencegahan ada di sekitar keluarga yaitu ketua RT, RW, tokoh masyarakat dan perangkat desa.

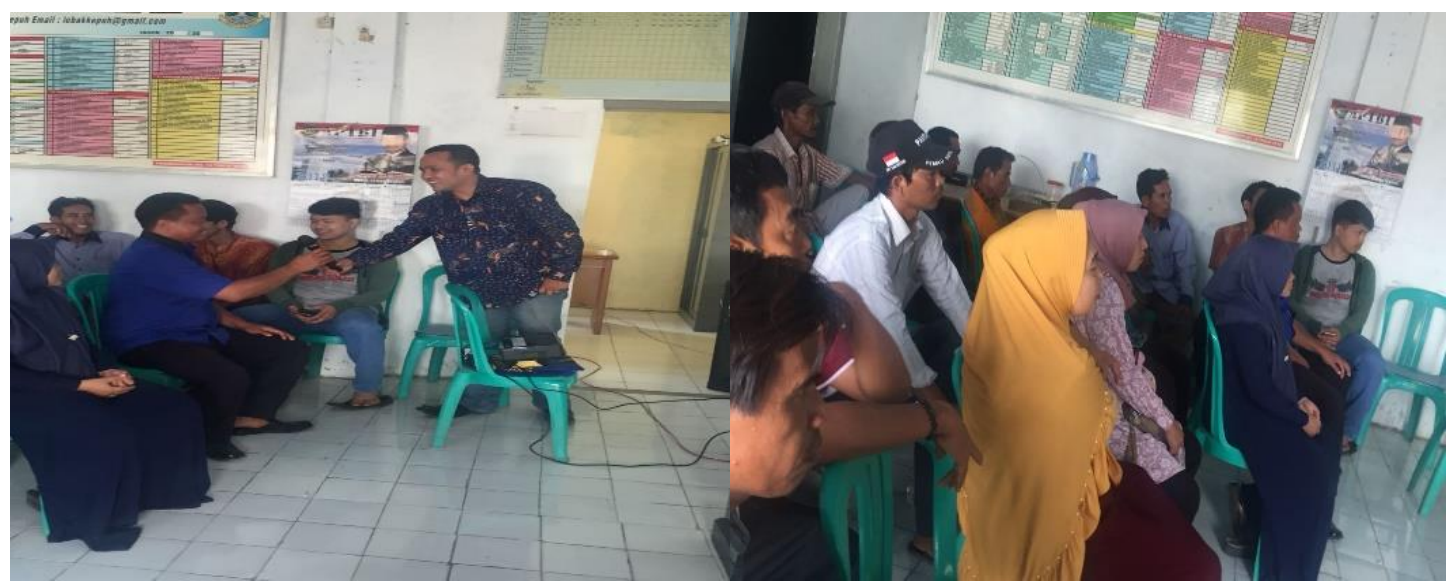

\section{Simpulan}

Faktor kemiskinan yang tidak kunjung berakhir sering kali menjadi factor utama seseorang atau keluarga melakukan Tindakan atau upaya-upaya untuk merubah kehidupan keluarga, salah satunya adalah dengan menjadi tenaga kerja wanita atau bekerja ke luar negeri. Factor Pendidikan yang rendah menjadi salah satu factor mudahnya korban tergiur dengan iming iming bekerja dan mendapatkan penghasilan yang tinggi tanpa memperhatikan kebenaran informasi tawaran kerja tersebut serta pihak-pihak yang diduga dapat membantu mengatasi masalah kemiskinan keluarga.

Pemerintah desa sebaiknya menjadi garda terdepan pencegahan tindak pidana perdagangan orang yang kerap terjadi pada daerah-daerah kantung kemiskinan dan daerah-daerah kantung tenaga kerja wanita di seluruh Indonesia.

Riswanda, Rahmawati. Sosialisasi dan Penyuluhan Undang-undang Nomor 21 tahun 2007 tentang Pemberantasan Tindak Pidana Perdagangan Orang di Desa Lebak Kepuh Kecamatan Lebak Wangi sebagai kantung TKW di Kabupaten Serang 


\section{Ucapan Terimakasih}

Ucapan terima kasih disampaikan kepada Dekan Fisip Untirta, Bapak Komalarudin, S. Sos selaku kepala Desa Lebak Kepuh dan seluruh jajarannya dan seluruh masyarakat Desa Lebak Kepuh yang telah berpartisipasi aktif dalam kegiatan pengabdian kepada masyarakat.

\section{Referensi}

Kasus perdagangan manusia, Indonesia tertinggi di dunia. Diunduh dari kanal 3.com

Kasus TKI di Malaysia paling banyak. Republika 22 Desember 2011. Diunduh dari Republika.com P2TP2A Provinsi Banten. 2014. Laporan jumlah kekerasan perempuan dan anak tahun 2013.
Penyebab perdagangan manusia diunduh dari www.gugus tugastrafficking.org

Syamsuri, dkk. 2011. Persepsi Keluarga tentang Motivasi Kaum Perempuan Menjadi TKW ke Luar Negara dan Pengaruhnya Terhadap Tingkat Kemiskinan (Studi di Kecamatan Lebak Wangi Kab Serang). Jurnal LPPM Untirta edisi 22 Vol3 Maret 2011.

Undang-Undang No. 21 Tahun 2007 tentang Pemberantasan Tindak Pidana Perdagangan Manusia.

US Embassy Report. Perdagangan Manusia. Diunduh dari key report US Embassy Report tahun 2013

Riswanda, Rahmawati. Sosialisasi dan Penyuluhan Undang-undang Nomor 21 tahun 2007 tentang Pemberantasan Tindak Pidana Perdagangan Orang di Desa Lebak Kepuh Kecamatan Lebak Wangi sebagai kantung TKW di Kabupaten Serang 